\title{
Evaluation effect of low level Helium- Neon laser and Iranian propolis extract on Collagen Type I gene expression by human gingival fibroblasts: an in vitro study
}

\author{
Hosein Eslami ${ }^{1}$, Paria Motahari ${ }^{2 *}$, Ebrahim Safari ${ }^{3}$, Maryam Seyyedi ${ }^{4}$ \\ 1: Assistant Professor, Department of Oral Medicine, Faculty of Dentistry, \\ Tabriz University of Medical Sciences, Tabriz, IR Iran \\ 2: Post graduate student. Department of Oral Medicine, Faculty of Dentistry, \\ Tabriz University of Medical Sciences, Tabriz, IR Iran \\ 3: Associate Professor of Physic, Department of atomic and molecular Physics, \\ Faculty of physics university of Tabriz, IR Iran \\ 4: PhD student of microbiology, tuberculosis and lung disease research center, \\ Tabriz University of medical science, Tabriz, Iran
}

\begin{abstract}
Back ground and aim: production of collagen by fibroblast cells is a key component in wound healing. Several studies have shown that low level laser therapy (LLLT) and propolis extract stimulate collagen Type I production. The aim of this study is to evaluation the combined effect of LLL helium neon $(632.8 \mathrm{~nm})$ and Iranian propolis extract on collagen Type I gene expression by human gingival fibroblasts (HGF3-PI 53).

Methods and materials: Human gingival fibroblasts after culturing divided into six experimental groups: G1-control group, which received no irradiation and propolis extract, G2-irradiated at1.5 $\mathrm{J} / \mathrm{cm}^{2}, \mathrm{G} 3$-irradiated at $0.15 \mathrm{~J} / \mathrm{cm}^{2}$, G4-recived extract of propolis, G5-combined extract of propolis and $1.5 \mathrm{~J} / \mathrm{cm}^{2}$ laser irradiation and G6- combined extract of propolis and $0.15 \mathrm{~J} / \mathrm{cm}^{2}$ laser irradiation. The experiments were conducted in triplicate. After 24 hour, the total RNA was extracted and cDNA synthesis was performed. Type I collagen mRNA expression was determined with real time PCR.

Results: The obtained results illustrated a statistically significant difference between G3 (0.15 $\mathrm{J} / \mathrm{cm}^{2}$ ) and G1 (control group) in levels of collagen Type I messenger RNA (mRNA) expression $(\mathrm{p}<0.05)$. The irradiated cells showed a 1.4 times increase in mRNA expression of the collagen Type I gene. Expression of this gene decreases in other groups that this difference was statistically significant.

Conclusion: LLLT in different dosage and propolis extract may result in decreased or increased collagen type I gene expression. However this effect should be investigated in clinical studies.
\end{abstract}

Key words: collagen Type I • Gene expression • Low-level laser therapy (LLLT) • propolis extract • Fibroblastic cell

\section{Introduction}

Oral mucosal wounds are open lesions in the mouth which are caused by various disorders ${ }^{1)}$. These wounds can be the final common manifestation of a

*Addressee for Correspondence:

Paria Motahari

Email: paria.motahari@yahoo.com

Faculty of Dentistry, Tabriz University of Medical Sciences,

Tabriz, IR Iran

Phone: 00989144197584 wide range of conditions including traumatic lesions, infectious, vesiculo-bullous, neoplastic and gastrointestinal diseases ${ }^{2}$. They may be life threatening by development of infection due to invasion of microorganisms or contaminants ${ }^{3}$ ). Oral mucosal wounds occur frequently, and the healing of these lesions is important. The wound healing procedure consists of four phases: hemostasis, inflammation, proliferation

Received date: December 16th, 2016 Accepted date:January 27th, 2017 
and tissue remodeling ${ }^{4)}$. Gingival fibroblasts as a connective tissue cells are responsible for collagen deposition which is a basic element in repair procedure of the tissue injury ${ }^{5)}$. These cells are able to produce collagen, elastin, fibronectin, and proteoglycans which play essential roles in gingival connective tissue. In normal tissues, strength, integrity and structure are provided by collagen. When tissues are disrupted due to injury, collagen acts to repair the defect and consequently restore anatomic structure and function. Normal anatomical structure is lost when too much collagen is deposited in the injury place, therefore function is compromised and fibrosis occurs. On the other hand, if an inadequate amount of collagen is deposited, the injury could be considered as weak and may dehisce ${ }^{6}$.

In recent decades, the use of lasers in physical medicine has become a consolidated practice. In spite of the numerous studies on the application of laser in the biomedical field, it is not easy to justify physical variables as: application technique, dosages, depth, modes and duration of exposure ${ }^{7)}$. Low-level lasers therapy (LLLT) as a useful tool has been increasingly used for improving wound healing ${ }^{8)}$. LLLT promotes tissue healing by increasing cell proliferation 9), promotes collagen synthesis and accelerates the formation of granulation tissue ${ }^{10,11)}$. Abergel et al confirmed that in fibroblast cultures, He-Ne and Ga-Al-As lasers certainly improve procollagen production without any effect on proliferation ${ }^{12)}$

Several researches in the past have focused on the use of natural medicines for healing Oral mucosal wounds. Therefore, some studies have evaluated the injury healing treated by propolis 13,14$)$. Propolis is a balsamic-resinous material with viscous consistency which is made by bees (Apis mellifera). One of its chemical components is flavonoid. It plays three main roles as antioxidants, antimicrobial agents, and modulators of the immune system ${ }^{15}$ ). Some components of propolis may play significant bio modulatory function on the dynamics of fibroblastic activity and collagen synthesis as well 16,17). Albuquerque-Junior et al demonstrated that the integration of Brazilian red propolis into collagen-based films could improve injury healing, because of modulating the dynamics of the inflammatory evolution and collagen deposition process ${ }^{18)}$

Ghaibi et al evaluated the combined effect of laser and oral administration of Iranian propolis extract on skin wound healing in male rats and showed that oral administration of propolis or low power laser radiation can increase the wound healing rate ${ }^{19)}$. In the past studies about collagen synthesis, the exact effect of propolis is still not fully clarified and optimal parameters of LLLT are still not defined. Therefore, the aim of our study was to evaluate single or combined effects of LLL helium neon (he-ne) and Iranian propolis extract on collagen type I gene expression of human gingival fibroblasts (HGF3-PI 53). Cell culture investigations facilitate an experimental environment in which the effect of LLLT and propolis extract on gingival fibroblasts can be investigated by eliminating many parameters that may interfere with clinical trials.

\section{Materials and Methods}

\section{Fibroblast cell culturing}

Human gingival fibroblasts (HGF3-PI 53 NCBI code C502) have been provided by Pasteur Institute, Iran. Culture process was performed according to the cell culture protocol of American Type Culture Collection (ATCC). The cells were cultured in RPMI (Gibco, USA) supplemented with 10\% fetal bovine serum (FBS). In addition, this medium was supplemented with $2 \mathrm{mM} \mathrm{L-}$ glutamine, $100 \mathrm{U} / \mathrm{ml}$ penicillin, and $100 \mu \mathrm{g} / \mathrm{ml}$ streptomycin. Culture media condition was changed every two days through the test procedure. Overlying liquid culture media was removed with micropipettes and 5 $\mathrm{ml}$ fresh culture media added to each $25 \mathrm{~cm}^{2}$ flask. Cell passage was performed. Cells initially were washed with phosphate buffered saline (PBS) followed by adding of $1 \mathrm{ml}$ trypsin solution $(0.25 \%)$ for $3 \mathrm{~min}$. Afterward, FBS $(5 \mathrm{ml})$ was added to neutralize the trypsin. The cells were removed by centrifugation at $1200 \mathrm{rpm}$. The cells were re-suspended in fresh culture medium and the cell suspension was transferred into three flasks. HGF3-PI 53 cells were grouped in three 6well plates at an initial density of $5 \times 10^{6}$ cells/well and incubated for $24 \mathrm{hr}$ at $37^{\circ} \mathrm{C}$ under $5 \% \mathrm{CO} 2$ atmosphere prior to exposure to laser irradiation and extract of propolis.

\section{Propolis extraction process}

Collected Propolis samples from different locations in Iran were used in this study. Hand-collected propolis was dried out in the dark before it's processing. The samples were ground mechanically and bottled in $10 \mathrm{~g}$ portions. The portions of $10 \mathrm{~g}$ were put into flasks, and $100 \mathrm{~g}$ of $70 \%$ ethanol (w/v, POCH S.A., Poland) was added. Propolis was subjected to 14 days of extraction in order to obtain ethanol extract of propolis (EEP). The flask was located in laboratory shaker in a dark, closed bottle for two weeks in ordinary temperature of 
laboratory. After that time, the extract was cooled in $3^{\circ} \mathrm{C}$ for 24 hours to precipitate all unsolvable substances. Rough particles were removed from the propolis extract, filtered using filter paper (Whatman no. 4, UK). The obtained filtrate was evaporated, by means of rotary vacuum evaporator (Rotavapor R-215, BUCHI Labortechnik AG, Switzerland), in $45^{\circ} \mathrm{C}$. In this path, a viscous substance having brown color was achieved, which was later dissolved in ethanol in order to receive $2 \mu \mathrm{g} / \mu \mathrm{L}$ of the working concentration. Our experiment has been started with high concentration of propolis extract $(70 \mu \mathrm{g} / \mu \mathrm{L})$, then the concentration of propolis extract has been decreased. Through this procedure, we reached to appropriate concentration $2 \mu \mathrm{g}$ / $\mu \mathrm{L}$. In this concentration, decrease in cell viability was not seen under light microscope while it was added into culture media. Finally, $1 \mu \mathrm{L}$ of this extract admixed with 1cc of media culture (RPMI $1640+$ FBS 10\%) of wells and cells incubated for 24 hours.

\section{Low level laser irradiation}

Laser irradiation was provided by means of a $632.8 \mathrm{~nm}$ helium neon (he-ne) laser and a maximal output power of $500 \mathrm{~mW}$. The wells were irradiated from $10 \mathrm{~cm}$ distance using a laser beam. The output laser beam was directed toward the center of the wells over a $9.6 \mathrm{~cm}^{2}$ zone during medium culture. Required irradiation time was $60 \mathrm{sec}$. The cells were irradiated $24 \mathrm{~h}$ after seeding and The Gene expression was assessed $24 \mathrm{~h}$ after irradiation.

Six experimental groups have been considered for the evaluation of laser's and propolis extracts bio modulation performance. These groups named as: G1control group, which received no irradiation and propolis extract; G2-irradiated at $1.5 \mathrm{~J} / \mathrm{cm}^{2}$; G3-irradiated at $0.15 \mathrm{~J} / \mathrm{cm}^{2}$; G4-recived extract of propolis; G5combined extract of propolis and $1.5 \mathrm{~J} / \mathrm{cm}^{2}$ laser irradiation and G6- combined extract of propolis and 0.15 $\mathrm{J} / \mathrm{cm}^{2}$ laser irradiation. It is worthy to note that, we performed all steps of this research in three times.

\section{Real-time PCR Primer Design}

Total RNA was extracted by the Gene Jet RNA Purification Kit (Thermo Scientific, USA) after 24 hours of incubation and cDNA synthesis was performed using Revert Aid First Strand cDNA Synthesis kit (Thermo Scientific, USA). The cDNA products were used for standard Real time Polymerase Chain Reaction (PCR). Real time PCR reactions were performed by Maxima $^{\text {TM }}$ SYBR/ROX qPCR Master Mix (Thermo Scientific, USA) and monitored in Rotor-gene $\mathrm{Q}$ realtime analyzer (Corbet, Australia). The effect of expres- sion of collagen type I was investigated by Real time PCR (data not shown) and alteration of the level of expression was assessed with RT-PCR in triplicate and followed by prediction of the average threshold cycle which was normalized with GAPDH. The fold change of each target gene was estimated using $\Delta \Delta \mathrm{CT}$ method. The primers were designed by primer 3 programs, and complete cDNA sequences obtained from the NIH Gene Bank Entrez program. The sequence of primers used is specified in Table $\mathbf{1}$.

\section{Statistical analysis}

Statistical analyses were performed in accordance with the Pfaffl method 20) and capability of the Reset2009 software application ${ }^{21)}$, taking into consideration the standard deviation values and the "pair wise fixed reallocation randomization test". A significance of $\mathrm{p}<0.05$ has assumed.

\section{Results}

The obtained results illustrated a statistically significant difference between G3 $\left(0.15 \mathrm{~J} / \mathrm{cm}^{2}\right)$ and G1 (control group) in levels of collagen type I messenger RNA (mRNA) expression $(\mathrm{p}<0.05)$. The irradiated cells showed a 1.4 times increase in mRNA expression of the collagen type I gene. Expression of this gene decreases in other groups compared to control group, that this difference was statistically significant $(\mathrm{p}<$ 0.05). Difference in other groups were statistically significant $(\mathrm{p}<0.05)$ when compared with each other except between (G2, G4), (G2, G5) and (G4, G5) groups (Fig. 1).

\section{Discussion}

In dentistry, LLLT has been widely studied to accelerate the healing process, especially in the treatment of ulcerative oral mucosal lesions 22, 23). One possible reason might be explained by augmenting mitotic activity ${ }^{24-26)}$, as well as by changes in collagen synthe-

Table 1: Primer sequences used to analyze the gene expression of irradiated cells

\begin{tabular}{ll}
\hline Gene & Primer sequences \\
\hline \multirow{3}{*}{ COLA1 } & F: 5'-GTGCGATGACGTGATCTGTGA-3' \\
& R: 5'-CGGTGGTTTCTTGGTCGGT-3 \\
\hline
\end{tabular}


sis $24,25,27-29)$. In this study, a low-power He-Ne laser (632.8 nm) was used to stimulate cultured human gingival fibroblasts. This laser was chosen because it is known that this wavelength could be optimal for wound healing ${ }^{30)}$. In the current study, most parameters related to the laser irradiation are constant (e.g., wavelength, power output, irradiated area, exposure times), except the energy densities. The laser wavelength was $632.8 \mathrm{~nm}$ with a power output of $5 \mathrm{mWand}$ the area covered by the light was of $9.6 \mathrm{~cm}^{2}$. Consequently, we have demonstrated that differences in energy density have different effects on cell growth. Our results corroborate with theories stating that low power laser can stimulate cell proliferation, but only within combination of exposition parameters, in a narrow energy, and power density bands 31 ). This shows that preventing effect on collagen gene expression achieved when using $1.5 \mathrm{~J} / \mathrm{cm}^{2}$. There is a controversy on the effect of laser irradiation on collagen metabolism. Some of past studies have shown LLLT had no effect on procollagen and collagen synthesis 11,32 ).

The majority of in-vitro studies have illustrated that the use of LLLT in a cell culture of fibroblasts and epithelial cells enhances cell proliferation and gene expression of collagen type I ${ }^{10,33-35)}$.

Pourzarandian et al showed that the low-level Er:YAG laser irradiation stimulates proliferation of cultured gingival fibroblasts. They showed that, the simulative action on gingival fibroblasts proliferation through the production of PGE2 via the expression of
COX-2 36, 37).

Based on the study of Martignago et al, the laser irradiation $\left(\lambda 904 \mathrm{~nm}\right.$ ) with a dose of $2 \mathrm{~J} / \mathrm{cm}^{2}$ increases the expression of collagen genes type I alpha 1 (COL1 11 ) in the fibroblast cells of mice (L929) cultivated in vitro ${ }^{38)}$. The study of Frozanfar et al. ${ }^{39)}$, shows that the influence of LLLT $(\lambda 810 \mathrm{~nm})$ on the expression of the COL1 gene has been evaluated, after three laser applications at $4 \mathrm{~J} / \mathrm{cm}^{2}$ in a culture of human gingival fibroblast. It was found that multiple applications of laser irradiation caused a stimulatory effect on the levels of COL1 mRNA. The irradiation of fibroblast cells derived from the Achilles tendon of pigs, by LLLT ( $\lambda$ 820 and $635 \mathrm{~nm}$ ) in doses of 1,2 , and $3 \mathrm{~J} / \mathrm{cm}^{2}$, had caused increase in the expression of mRNA of the COL1 gene $24 \mathrm{~h}$ after a single exposure to irradiation with all doses employed ${ }^{40)}$. An experimental study on gingival fibroblast culture showed that irradiation with diode laser increases the production of the corresponding mRNA for the synthesis of collagen type I ${ }^{41)}$. An experimental test by Chellini et al. using Nd:YAG laser for LLLT $\left(1.5 \mathrm{~J} / \mathrm{cm}^{2}\right.$ ), showed that fibroblasts' (cell line derived from mice NIH/3T3 fibroblasts) irradiation LLLT resulted in significant production of collagen type I ${ }^{42)}$. There are significant differences between other studies and current research work including wavelength and cell types, frequency, energy, optic fiber diameter, time, and distance of irradiation. Therefore a direct comparison cannot be implied herein. Our results confirm that the data found in the cell cultures

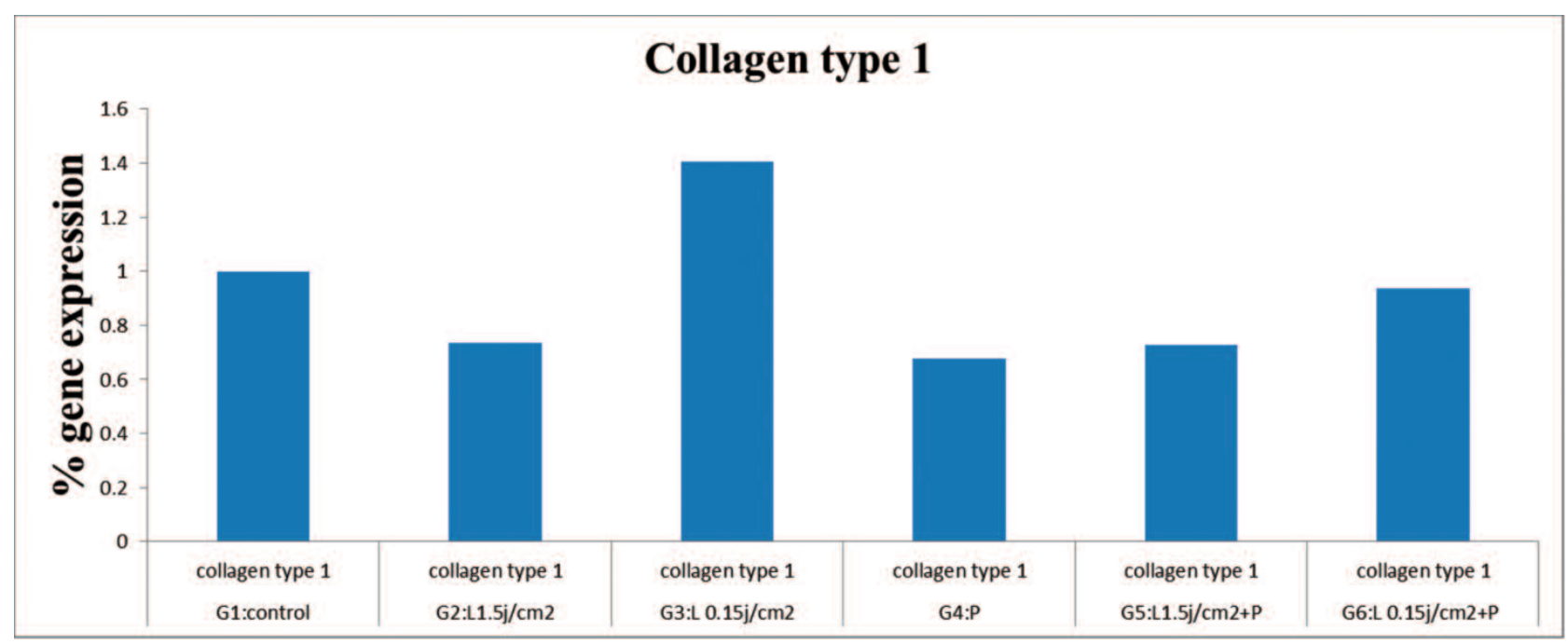

Fig. 1: Relative expression of the collagen type I gene; L: laser, P: propolis 
of human fibroblasts, after laser applications ( $\lambda$ $632.8 \mathrm{~nm}$ ) at a dose of $0.15 \mathrm{~J} / \mathrm{cm}^{2}$ in the gingival fibroblast cells of human, a bio modulation effect increasing the expression of the COL1 gene was observed. In addition, we observed decrease in the expression of the COL1 gene for a dose of $1.5 \mathrm{~J} / \mathrm{cm}^{2}$. This result suggests an inhibitory effect on the expression of this gene by the dose used. Hakki and Bozkurt 43) illustrated that irradiation of human gingival fibroblast at a wavelength of $904 \mathrm{~nm}\left(6 \mathrm{~J} / \mathrm{cm}^{2}\right)$ seriously reduced the expression of collagen type $I$ in the periodontal pocket application when compared to the no irradiated control, bio stimulation, and infected pocket groups. Moreover, studies by Houred et al. ${ }^{44)}$ established a down regulation of $\operatorname{COL} 1 \alpha 1, \operatorname{COL} 1 \alpha 2$, COL $3 \alpha 1$, COL $5 \alpha 1$, and COL $5 \alpha 2$ in response to irradiation of fibroblast cells as $660 \mathrm{~nm}$ and diode laser at an effect of $5 \mathrm{~J} / \mathrm{cm}^{2}$. We showed it selectively restrained collagen products in fibroblast culture which recommend that this laser modality may be useful for the cure of fibrosis condition as keloids and hypertrophic scar, scleroderma and oral submucose fibrosis.

The main focuses of past researches that evaluated the effect of propolis extract on collagen synthesis were often on animal models. Increase in collagen deposition in wounds treated with ethanolic extract of propolis has been observed in some of them 45-48). Kilicoglu et al. ${ }^{49)}$ showed better performance of fibroblast proliferation, activation and synthesis capabilities in the presence of propolis. Oliveira et al. ${ }^{45}$ ) found a similar view that propolis speeds up the healing procedure both through its anti-inflammatory effect, and by direct action on fibroblast proliferation. Günay et al. ${ }^{50)}$ used propolis gel to evaluate its result on fibroplasia in post tooth extraction wounds. They illustrated that it had no significant effect on fibroblast expansion. In vitro studies assessed the effect of propolis on cytotoxicity and proliferation of fibroblast cells that included its high or mild cytotoxicity 51, 52), or no effect ${ }^{53}$ ), and the proliferative action of this product ${ }^{54}$ ), depending on several factors as concentration, exposure time, and the in vitro /in vivo conditions. The effect of different alcoholic propolis solution was evaluated on cultures of fibroblast. Results illustrated that lower concentration of propolis (1\%, $2 \%$ or $4 \%)$ were more efficient and not toxic to the fibroblasts 55 ). In the study of Ann Jacob et al, Malaysian propolis showed maximum proliferation of fibroblast at 500 $\mu \mathrm{g} / \mathrm{mL}$ with no significant difference (i.e. $\mathrm{p}>0.05$ ) compared to control group. Brazilian red propolis showed a slight increase in proliferation at 10 and 100 $\mu \mathrm{g} / \mathrm{mL}$ concentrations, respectively with no significant difference ( $p>0.05$ ) compared to control, while concentrations above these had inhibitory effects 56). An opposing observation on the effect of Tubi-bee propolis on glioblastoma and normal fibroblast cell lines has been reported by Borges et al. ${ }^{57)}$. They concluded that propolis exerted a strong inhibition on the proliferation of both cell lines. Funari et al. ${ }^{51)}$ observed that concentration of $31.25 \mu \mathrm{g} / \mathrm{mL}$ of propolis was contaminated to mouse fibroblasts where it caused a $50 \%$ decrease in cell viability. In the study of Małgorzata, propolis at a concentration of $100 \mu \mathrm{g} / \mathrm{mL}$ decreased cell growth $27 \%$ when it was compared with the controlling case ${ }^{58)}$. In the present study, we observed decrease in expression of collagen type I gene of fibroblasts that were exposed with propolis extract, probably due to toxic effect of propolis on fibroblast cells. As a result, combined effect of propolis extract and laser irradiation have decreased expression of collagen type I gene. This finding does not exclude the possibility of other changes in the collagen metabolism. It could also provide an important indication that high energy LLLT treatment could not ensure the best clinical stimulation effects .That is to say, suitably determined laser density might cause optimal treatment effects in gingival tissue healing. Nevertheless, the real advantages of in vivo studies needs further resolve. This study also shows that the mRNA expressions of collagen type I increase irrespective of the energy density. Hence, some latent effects may be seen on fibroblasts after different treatments of LLL.

While this study addresses gene expressions under low level laser irradiation (LLLI) and propolis extract in vitro, there are some limitations to the study which could be considered in future studies. First, our study design involved a $24 \mathrm{~h}$ result after LLLI. It is not obvious that what the accumulated effect of longer durations on gene expressions is. Our study focused on the gene expressions of collagen type I, however many components are required for the gingival tissue to undergo healing processes. Other components of this matrix may respond differently to LLLI and propolis extract. Finally, though animal models have been helpful, particularly with regard to the gingiva, any suggestion that the results derived from an in vitro animal model would necessarily apply to an in vivo human gingiva should be treated with caution. In summary, the production of mRNA increases under LLLI. mRNA expressions by varying the dosage of LLLI highlights the fact that effective irradiation energy may reach maximal effects in connective tissue healing. The optimal LLLI dose for mRNA expressions of collagen type $\mathrm{I}$ in this study was found to be $0.15 \mathrm{~J} / \mathrm{cm}^{2}$. It is 
hoped that a deep understanding of the dosage effects of gene expressions is achieved while applying LLLI will lead to greater insight into both the injury and rehabilitation of the gingival tissue.

\section{Conclusion}

Based on the results of the present study, it has been illustrated that LLLT within the parameters presented is capable of stimulating the expression of the collagen type I genes in a culture of the human gingival fibrob-

\section{Reference}

1: Gonsalves WC, Chi AC, Neville BW (2007): Common oral lesions: Part I. Superficial mucosal lesions. Am Fam Physician, 75:501-507.

2: Campisi G, Compilato D, Cirillo N, Ciavarella D, Panzarella V, Amato S, Lo Muzio L (2007): Oral ulcers: three questions on their physiopathology. Minerva Stomatol, 56:293-302.

3: Markiewicz MR, Margarone III JE, Barbagli G, Scannapieco FA (2007): Oral Mucosa Harvest: An Overview of Anatomic and Biologic Considerations. EAU-EBU Update Series, 5:179-187.

4: Robins SP, Milne G, Duncan A, Davies C, Butt R, Greiling D, James IT (2003): Increased skin collagen extractability and proportions of collagens type III are not normalized after 6 months healing of human excisional wounds. J Invest Dermatol, 121: $267-72$

5: Ross R (1969): Wound healing. Sci Am, 220: 40.

6: Lazarus G S, Cooper D M, Knighton DR, Margolis DJ, Pecoraro RE, Rodeheaver G and Robson MC(1994): Definitions and guidelines for assessment of wounds and evaluation of healing. Arch Dermatol, 130: 489.

7: England S (1988): Introduction to mid laser therapy. Physiotherapy, 74:100-3.

8: Mester E, Nagylucskay S, Döklen A, Tisza S (1976): Laser stimulation of wound healing. Acta Chir Acad Sci Hung, 17:49-55.

9: Almeida-Lopes L, Rigau J, ZaÃngaro RA (2001): Comparison of the low level laser therapy effects on cultured human gingival fibroblasts proliferation using different irradiance and same fluence. Lasers Surg Med, 29:179-84.

10: Skinner SM, Gage JP, Wilce PA (1996): A preliminary study of the effects of laser radiation on collagen metabolism in cell culture. Aust Dent J, 41:18892. last cells. Those cells irradiated with $0.15 \mathrm{~J} / \mathrm{cm}^{2}$ showed increase in gene expression of the COL type I gene, when those irradiated at $1.5 \mathrm{~J} / \mathrm{cm}^{2}$ or received propolis extract or combined laser $\left(0.15 \mathrm{~J} / \mathrm{cm}^{2}\right.$ or 1.5 $\mathrm{J} / \mathrm{cm}^{2}$ ) and propolis extract showed decrease in expression of this gene. It is worth to note that the gene expression of collagen has just been evaluated in this paper and more researches based on western blot or ELISA results for detection of collagen protein are suggested.

11: Pereira AN, Eduardo Cde P, Matson E (2002): Effect of low power laser irradiation on cell growth and procollagen synthesis of cultured fibroblasts. Lasers Surg Med, 31:263-7.

12: Abergel RP, Lam TS, Meeker CA, Castel JC (1984): Biostimulation of procollagen production by low energy lasers in human skin fibroblast cultures. J Invest Dermatol, 82:395-402.

13: Arvouet-Grand A, Lejeune B, Bastide P, Pourrat A, Privat AM, Legret P(1993): Extrait de propolis: II. Etude de la cicatrisation de plais chez le palin et chez le rat. J Pharm Belg, 48: 171-178.

14: Magro-Filho O, Carvalho ACP (1994): Topical effect of propolis in the repair of sulcoplasties by the modified kazanjian technique. J Nihon Univ Sch Dent, 36: 102-111.

15: Burdock G (1998): Review of the biological properties and toxicity of bee propolis (propolis). Food Chem Toxicol, 36: 347-363.

16: Sehn E, Hernandes L, Franco SL, Gonçalves CC, Baesso MLN (2009): Dynamics of reepithelialisation and penetration rate of bee própolis formulation during cutaneous wounds healing. Acta Chim. Acta, 635:115-20.

17: McLennan SV, Bonner J, Milne S, Lo L, Charlton A, Kurup S, Jia J, Yue DK, Twigg SM (2008): The antiinflammatory agent Própolis improves wound healing in a rodent model of experimental diabetes. Wound Repair Regen, 16:706-13.

18: Albuquerque-Junior RLC,Barreto SAL, Pires AJ, Reis PF, Lima OS, Riberio GMA, Cardoso CJ (2009): Effect of bovine type-I collagen-based films containing red propolis on dermal wound healing in rodent model. Int J Morphol, 27:1105-1110.

19: Ghaibi N, Sofiabadi M, Farzam A, Homayonizade M, Sadat-Afzali M (2015): The combined effect of laser and oral administration of Iranian propolis 
extract on skin wound healing in male rats. J Kermanshah Univ Med Sci, 9:62-7.

20: Pfaffl MW (2001): A new mathematical model for relative quantification in real-time RT-PCR. Nucleic Acids Res, 29: 2003-2007.

21: Pfaffl MW, Horgan GW, Dempfle L (2010): Relative expression software tool (REST) for group-wise comparison and statistical analysis of relative expression results in realtime PCR. Nucleic Acids Res, 30: 1-10.

22: Chor A, Azevedo AM, Maiolino A, Nucci M (2004): Successful treatment of oral lesions of chronic lichenoid graft-vs.-host disease by the addition of low-level laser therapy to systemic immunosuppression. European Journal of Hematology, 72:222-224.

23: Abramoff MMF, Lopes NNF, Lopes LA (2008): Lowlevel laser therapy in the prevention and treatment of chemotherapy-induced oral mucositis in young patients. Photomedicine and Laser Surgery, 26: 393-400.

24: Pourreau-Schneider N, Soudry M, Remusat M, Franquin JC, Martin PM (1989): Modifications of growth dynamics and ultrastructure after heliumneon laser treatment of human gingival fibroblasts. Quintessence Int, 20:887-893.

25: van Breugel HHFI, Dop Ba"r PR (1992): Power density and exposure time of He-Ne-laser irradiation are more important than total energy dose in photo-biomodulation of human fibroblasts in vitro. Lasers Surg Med, 12:528-537.

26: Almeida-Lopes L, Rigau J, Zngaro RA, Guiduli-Neto J, Jaeger MMM (2001). Comparison of the low level therapy effects on cultured gingival fibroblasts proliferation using different irradiance and fluence. Lasers Surg Med, 29: 179-184.

27: Yew DT, Li WWY, Pang KM, Mok YC, Au C (1989): Stimulation of collagen formation in the intestinal anastomosis by low dose He-Ne laser. Scanning Microsc, 3:379-386.

28: Yamamoto Y, Kono T, Kotani H, Kasai S, Mito M (1996): Effect of low-power laser irradiation on procollagen synthesis in human fibroblasts. J Clin Laser Med Surg, 14:129-132.

29: Reddy GK, Stehno-Bittel L, Enwemeka CS (1998): Laser photostimulation of collagen production in healing rabbit achilles tendons. Lasers Surg Med, 22:187-281.

30: Conlan M J, Rapley JW, Cobb CM (1996): Biostimulation of wound healing by low-energy laser irradiation. J Clin Periodontol, 23:492-6.

31: Loevschall H, Arenholt-Bindslev D (1994): Effect of low level diode laser irradiation of human oral mucosa fibroblasts in vitro. Lasers Surg Med, 14:347-354.

32: Colver BG,Priestely GC (1989): Failure of a helium neon laser to affect component of wound healing in vitro. Br J Dermatol, 121:179-86.

33: KhadraM, Lyngstadaas SP, Haanaes HR,Mustafa $\mathrm{K}$ (2005): Effect of laser therapy on attachment, proliferation and differentiation of human osteoblastlike cells cultured on titanium implant material. Biomaterials, 26: 3503-3509.

34: Kreisler M, Christoffers AB, Al-Haj H, Willershausen B, d'Hoedt B (2002): Low level 809$\mathrm{nm}$ diode laser-induced in vitro stimulation of the proliferation of human gingival fibroblasts. Lasers Surg Med, 30:365-369.

35: Azevedo LH, de Paula EF, Moreira MS, de Paula EC, Marques MM (2006): Influence of different power densities of LILT on cultured human fibroblast growth: a pilot study. Lasers Med Sci, 21:86-89.

36: Pourzarandian A, Watanabe H, Ruwanpura SMPM, Aoki A, Noguchi K, Ishikawa I (2005): Er: YAG laser irradiation increases prostaglandin E2 production via the induction of cyclooxygenase- 2 mRNA in human gingival fibroblasts. J Periodont Res, 40:182-186.

37: Pourzarandian A, Watanabe H, Ruwanpura SMPM, Aoki A, Ishikawa I (2005): Effect of low-level Er YAG laser irradiation on cultured human gingival fibroblasts. J Periodontol, 76:187-193.

38: Martignago CCS, Oliveira RF, Pires-Oliveira DAA, Oliveira PD, Pacheco Soares C, Monzani PS, PoliFrederico RC (2015): Effect of low-level laser therapy on the gene expression of collagen and vascular endothelial growth factor in a culture of fibroblast cells in mice. Lasers Med Sci, 30:203-208.

39: Frozanfar A, Ramezani M, Rahpeyma A, Khajehahmadi S, Arbab HR (2013) The effects of low level laser therapy on the expression of collagen type $i$ gene and proliferation of human gingival fibroblasts (Hgf3-Pi 53): in vitro study. Iran J Basic Med Sci, 16:1071-74

40: Chen CH, Wang YH, Lee CL, Chen JK, Huang MH (2009): Low level laser irradiation promotes cell proliferation and mRNA expression of type I collagen and decorin in porcine achilles tendon fibroblasts in vitro. J Orthop Res, 28:646-650.

41: Chen YJ, Jeng JH, Lee BS, Chang HF, Chen KC, Lan WH (2000): Effects of Nd:YAG laser irradiation on cultured human gingival fibroblasts. Lasers in Surgery and Medicine, 27:471-478.

42: Chellini F, Sassoli C, D Nosi (2010): Low pulse 
energy Nd:YAG laser irradiation exerts a biostimulative effect on different cells of the oral microenvironment: 'an in vitro study. Lasers in Surgery and Medicine, 42: 527-539.

43: Hakki SS, Bozkurt SB (2012): Effects of different setting of diode laser on the mRNA expression of growth factors and type I collagen of human gingival fibroblasts. Lasers Med Sci, 27:325-331.

44: Houreld NN, Ayuk SM, Abrahamse H (2014): Expression of genes in normal fibroblast cells (WS1) in response to irradiation at $660 \mathrm{~nm}$. J Photochem Photobiol B, 130:146-52.

45: Oliveira DWD, Lima NL, Verli FD, Miranda JL (2013): Fibroplasia in oral surgical wounds submitted to topical Brazilian Propolis. Basic Res J Med Clin Sci, 2: 5-10.

46: Moraes LT, Trevilatto PC, GrégioAMT, Machado MAN, Lima AAS (2011): Quantitative analysis of mature and immature collagens during oral wound healing in rats treated by brazilian propolis. J Int Dent Med Res, 4: 106-111.

47: Ocakci A, Kanter M, Cabuk M, Buyukbas S (2006): Role of caffeic acid phenethyl ester, an active component of propolis, against NAOH-induced esophageal burns in rats. Int $\mathrm{J}$ Pediatr Otorhinolaryngol, 70: 1731-9.

48: Abdel-Wahed RE, El-Kammar MH, Korittum AS, Edrees IR (2013): Evaluation of the Effectiveness Surgical and Histological of Propolis on Wound Healing. Alexandria Journal of Veterinary Sciences, 39:52-63

49: Kilicoglu SS, Kilicoglu B, Erdemli E (2008): Ultrastuctural view of colon anastomosis under propolis effect by transmission electron microscopy. World Journal of Gastroenterology, 14:4763-4770.

50: Günay A, Arpag OF, Atilgan S, Yaman F, Atalay Y, Acikan I (2014): Effects of caffeic acid phenethyl ester on palatal mucosal defects and tooth extraction sockets. Drug Des Devel Ther, 8:2069-74.

51: Funari CS, Oliveira Ferro V, Mathor MB (2007): Analysis of propolis from Baccharis dracunculifolia DC (Compositae) and its effects on mouse fibroblasts. J Ethnopharmacol, 111:206-212

52: Özan F, Sümer Z, Polat ZA, Er K, Özan U, Deger O (2010): Effect of mouthrinse containing propolis on oral microorganisms and human gingival fibroblasts. Eur J Dent, 1:195-201.

53: Pratsinis H, Kletsas D, Melliou E, Chinou I (2010): Antiproliferative activity of Greek propolis. J Med Food, 13:286-290.

54: Gjertsen AW, Stothz KA, Neiva KG, Pileggi R (2011): Effect of propolis on proliferation and apoptosis of periodontal ligament fibroblasts. Oral Surg Oral Med Oral Pathol Oral Radiol Endod, 112: 843-848.

55: Al-Shaher A, Wallace J, Agarwal S, Bretz W, Baugh D (2004): Effect of propolis on human fibroblasts from the pulp and periodontal ligament. J Endod, 30: 359-61.

56: Ann J, Abhishek P, Allan P, Fabian DA (2015): The effects of Malaysian propolis and Brazilian red propolis on connective tissue fibroblasts in the wound healing process. BMC Complementary and Alternative Medicine, 15:294.

57: Borges KS, Brassesco MS, Scrideli CA, Soares AEE, Tone LG (2011): Antiproliferative effects of Tubibee propolis in glioblastoma cell lines. Genet Mol Bio, 134:310-4.

58: Tyszka-Czochara M, Pa ko P, Reczy ski W, Szlósarczyk M, Bystrowska B, Opoka W (2014): Zinc and Propolis Reduces Cytotoxicity and Proliferation in Skin Fibroblast Cell Culture: Total Polyphenol Content and Antioxidant Capacity of Propolis. Biol Trace Elem Res, 160:123-131. 